\title{
Effect of Locality, Host Species and Sex on the Metazoan Parasitic Infestation of Two, Species of Scarus Fish from the Red Sea Coast at Jeddah and Rabigh in Saudi Arabia
}

\author{
Areej 0. Bakhraibah \\ Zoology Department Jeddah, Faculty of Science Al Faisaliah, King Abdelaziz University, Jeddah, KSA \\ Email: abakhraibah@gmail.com
}

How to cite this paper: Bakhraibah, A.O. (2018) Effect of Locality, Host Species and Sex on the Metazoan Parasitic Infestation of Two, Species of Scarus Fish from the Red Sea Coast at Jeddah and Rabigh in Saudi Arabia. Open Journal of Animal Sciences, 8, 252-258.

https://doi.org/10.4236/ojas.2018.83019

Received: March 18, 2018

Accepted: July 2, 2018

Published: July 5, 2018

Copyright $\odot 2018$ by authors and Scientific Research Publishing Inc. This work is licensed under the Creative Commons Attribution International License (CC BY 4.0).

http://creativecommons.org/licenses/by/4.0/

(c) (i) Open Access

\begin{abstract}
A total number of 60 specimens of two different species of Scarus fish caught from the Red Sea coast at Jeddah (30) and Rabigh (30) cities in Saudi Arabia were examined to determine their metazoan parasitic fauna, their prevalences, and mean intensities. Collected parasites were identified as, Isopoda (praniza larva of Gnathia sp.), Copepoda (Hatschekia sp.) Monogenea (Diplectanum sp.) and Digenea (Lecithoclaster and Bucephalus spp). Out of 30 specimens of fish caught from Jeddah coast 13 (43.4\%) were infested by 90 parasites comprising of two parasite species, praniza larva and Hatschekia sp., with prevalence of infestation $40 \%$ and $3.33 \%$, and mean intensity 7 and 6 parasites per fish respectively. 19 (63.3\%) of Scarus fish caught from Rabigh coast were infested by 205 parasites representing 4 parasite spp. Diplectanum sp. represents the most commonly encountered parasite with prevalence (53.3\%) and mean intensity (10.94\%), followed by (Lecithoclaster sp. then praniza larva, prevalances (16.66\% and $13.3 \%$ ) and mean inentisities (3.4. and 1.75) respectively. Bucephalus sp. showed the minor, prevalence (3.33\%) and mean intensity (6). Generally Scarus fish species from Rabigh had higher prevalence and mean intensity (63.3\% and 7.59\%) than Scarus fish species from Jeddah ( $43.4 \%$ and $6.92 \%)$. Female fish from Jeddah showed no parasitic infestation, while males were infested (prevalence 65\% and mean intensity 6.92). Female fish from Rabigh had higher prevalence (84.21) and lower intensity (6.43) than males which showed prevalence (27.27\%) and intensity (19). Relationship between parasitic infestation and fish species and sex were also studied in the two different localities and discussed.
\end{abstract}

\section{Keywords}

Scarus Fish, Metazoan Parasites, Prevalence, Intensity, Fish Species, Fish Sex, 
Red Sea

\section{Introduction}

Both wild and farmed marine fish face a wide range of threats, including parasites that impair their health, growth, and survival. Such parasite-related threats cause economic losses to fish farmers [1].

Among the parasites affecting fish health are parasitic crustaceans and monogenetic trematodes that cause severe destruction of fish gills, leading to anemia and death [2] [3]. Multiple factors can alter the relationships between host fishes and their parasites [4] [5] [6] [7].

Monogenea and parasitic crustaceans (Isopoda and Copepda) as well as digenetic trematodes have been studied in various species of Scarus fish (Scaridae) worldwide.

Jones and Cabral [8] described Hatschekia manea (Copepoda) from the gills of Scarus gibbus in the South Pacific Ocean. The variability in the interactions between seven reef fish species (including Scarus sordidas) and their ectoparasitic fauna were studied by Alexandra [9] from Australia. Williams and Bunkly-Williams [10] recorded Nerocila california (Isopoda) from the external body surface and gills of Scarus compressus from the Eastern Pacific Ocean. Parasitic crustaceans, including praniza larvae of Gnathia sp. and Hatschekia leptoscari, were described and recorded by Toulah [11] and Bakhrebah [12] from Scarus ferrugineus from the Red Sea by Jeddah, Saudi Arabia. Morsy et al. [3] described Diplectanum harid (Monogenea) from the gills of the parrotfish Scarus harid from the Red Sea near Hurghada, Egypt. Kardousha [13] studied the helminth parasites of 51 marine fish species from the Arabian Gulf and referred to the infestation of the parrot fish Scarus gobban with digenetic trematoda and acanthocephala. Some of the ecto- and endoparasites of Scarus fish, (praniza larva, Hatshekia, Bucephalus and Lecithocladium spp.) were also recorded from other different fishes from the Red Sea coast of Jeddah city in Saudi Arabia [11] [14] [15]. Most of the previous mentioned studies were taxonomic.

The aim of the present investigation is to review the different types of metazoan parasites infesting two different species of Scarus fish (Family Scaridae) from the Red Sea coast of Saudi Arabia with special reference to their host-parasite relationship.

\section{Materials and Methods}

The present study was carried out on total number of 60 specimens of two different species of Scarid, parrot fish (Family Scaridae). Each species consisted of 30 fish of different sexes, one caught from Jeddah and the other from Rabigh cities at the Red Sea coast of Saudi Arabia.

Captured fishes were freshly brought to the laboratory and their sexes were 
determined. Skin surface, fins and gills were visually examined for any external parasites with the help of a dissecting microscope. Visceral organs of fish were slit open and their contents were collected in Peteri dishes then examined under a dissecting microscope. Copepoda and Isopoda were preserved in $10 \%$ buffered formalin and cleared with lactophenol. Trematodes were preserved in formalin-alcohol-acetic acid and stained with Semichons acetic carmine stain.

Statistical analyses were done by using Mann Whitney $U$ test or student t-test. Significant level was at 0.05 .

\section{Results}

Parasitological examination revealed that Scarus fish under consideration harboured Monogenea, Isopoda and Copepoda on their gills and Digenea in their intestines. Table 1 represents the five species of parasites collected from the two different species of Scarus fish of Jeddah and Rabigh, their prevalences and mean intensities.

Diplectanum sp. from Scarus sp. of Rabigh was the most common parasite, followed by praniza larva from Scarus $s p$. of Jeddah, followed by Lecithoclaster $s p$. from Scarus sp. of Rabigh. Hatschekia and Bucephalus spp. were the minority. Generally Scarus fish species from Rabigh had higher prevalence and mean intensity of parasite than those from Jeddah. Monogenea and Digenea were not represented in Scarus fish from Jeddah as well as Copepoda in Scarus fish from Rabigh. Difference in the prevalence of infestations and parasite intensities for

Table 1. Prevalence (\%) and intensity ( $\mathrm{M} \pm$ S.E.) of different parasites infesting the two Scarus fish species from Jeddah and Rabigh.

\begin{tabular}{|c|c|c|c|c|c|c|c|c|}
\hline \multirow[b]{2}{*}{ Parasite sp. } & \multicolumn{4}{|c|}{ Jeddah } & \multicolumn{4}{|c|}{ Rabigh } \\
\hline & $\begin{array}{l}\text { No. of fish } \\
\text { Infected (\%) }\end{array}$ & $\begin{array}{l}\text { No. of } \\
\text { parasite }\end{array}$ & $\begin{array}{l}\text { Mean intensity } \\
\quad \text { (range) }\end{array}$ & $\mathrm{M} \pm \mathrm{S} . \mathrm{E}$ & $\begin{array}{l}\text { No. of fish } \\
\text { Infected (\%) }\end{array}$ & $\begin{array}{l}\text { No. of } \\
\text { parasite }\end{array}$ & $\begin{array}{l}\text { Mean intensity } \\
\quad \text { (range) }\end{array}$ & $M \pm S . E$ \\
\hline $\begin{array}{c}\text { Monogenea: } \\
\text { Diplectanum sp. }\end{array}$ & - & - & - & - & $16(53.3)$ & 175 & $10.94(2-30)$ & $10.94 \pm 2.85$ \\
\hline $\begin{array}{c}\text { Isopoda: Praniza larva of } \\
\text { Gnathisa sp. }\end{array}$ & $12(40)$ & 84 & $7(1-15)$ & $7 \pm 1.66$ & $4(13.3)$ & 7 & $1.75(1-3)$ & $1.75 \pm 0.48$ \\
\hline Copepoda: Hatschekia sp. & $1(3.33)$ & 6 & $6(6)$ & - & - & - & - & - \\
\hline $\begin{array}{c}\text { Digenea: } \\
\text { Bucephalus sp. }\end{array}$ & - & - & - & - & $1(3.33)$ & 6 & $6(6)$ & - \\
\hline Lecithoclaster sp. & - & - & - & - & $5(16.66)$ & 17 & $3.4(2-5)$ & $3.4 \pm 0.68$ \\
\hline Total Digenea & - & - & - & - & $6(20)$ & 23 & $3.8(2-6)$ & $3.8 \pm 0.70$ \\
\hline No. of fish examined & \multicolumn{4}{|c|}{30} & \multicolumn{4}{|c|}{30} \\
\hline No. of fish infected (\%) & $13(43.4)$ & - & - & - & $19(63.3)$ & - & - & - \\
\hline No. of Parasite species & - & 2 & - & - & - & 4 & - & - \\
\hline No. of Parasites & - & 90 & - & - & - & 205 & - & - \\
\hline Total mean intensity & - & - & $3.92(1-15)$ & $6.92 \pm 1.53$ & - & - & $7.59(1-30)$ & $7.59 \pm 1.86$ \\
\hline
\end{tabular}


each fish species in the two different localities was not significant (significant value $=0.651$ ).

All female Scarus fish of Jeddah were not infested. Males of the same species were infested with praniza larva of Gnathia $s p$. and Hatschekia sp. with overall prevalence (65\%) and mean intensity 6.92 (Table 2). Male Scarus fish from Rabigh were infested with only one parasite species, Diplectanum $s p$. (prevalence $27.3 \%$ and mean intensity 19) while females showed higher prevalence and lower intensity of monogenetic infestation than male fishes and were infested with four parasite species, with overall prevalence and mean intensity of parasite (84.2\%) and (6.43) respectively (Table 3 ).

Statistical analysis showed significant difference in the prevalence and mean intensity of parasite between female and male fish (Significant value $=0.029$ ).

\section{Discussion}

The present study, up to our knowledge, is the first done in Saudi Arabia Red Sea coast (Jeddah and Rabigh) to show the parasitic fauna (type and number of species and degree of parasitic infestation in relation to some factors) in two species of Scarus fish.

Distinct variation in composition of the parasitic fauna was noted in the two different localities. In Jeddah, Scarus fish was infested with parasitic Crustacea on their gills (Isopoda and Copepoda) while in Rabigh it was infested with Trematoda (Monogenea on their gills and Digenea in their intestines). Bauer [16] and Ramadan and Shakweer [17] reported that the type and rate of parasitic infestation in fishes depend on ecological and hydrobiological conditions of water. Barse [5] investigated the prevalence and intensities of gill parasites of Fundulus heteroclitus from two creeks different in salinity. He found that parasite densities were greater in the less saline creek for all collected parasite taxa.

Host specificity phenomenon was well established in this work where Monogenea, Diplectanum $s p$. showed the highest prevalence and mean parasitic intensity

Table 2. comparison of prevalence (\%) and intensity (M \pm S.E.) of different parasites infecting female and male examined Scarus fish in Jeddah.

\begin{tabular}{|c|c|c|c|c|c|c|c|c|}
\hline \multirow[b]{2}{*}{ Parasite sp. } & \multicolumn{4}{|c|}{ Female } & \multicolumn{4}{|c|}{ Male } \\
\hline & $\begin{array}{l}\text { No. of fish } \\
\text { Infected (\%) }\end{array}$ & $\begin{array}{c}\text { No. of } \\
\text { parasite }\end{array}$ & $\begin{array}{c}\text { Mean intensity } \\
\text { (range) }\end{array}$ & $\mathrm{M} \pm$ S.E. & $\begin{array}{l}\text { No. of fish } \\
\text { Infected (\%) }\end{array}$ & No. of parasite & $\begin{array}{l}\text { Mean intensity } \\
\quad \text { (range) }\end{array}$ & $\mathrm{M} \pm$ S.E. \\
\hline $\begin{array}{c}\text { Isopoda: Praniza larva of } \\
\text { Gnathisa sp. }\end{array}$ & 0.00 & 0.00 & 0.00 & 0 & $12(60)$ & 84 & $7(1-15)$ & $7 \pm 1.66$ \\
\hline Copepoda: Hatshekia sp. & 0.00 & 0.00 & 0.00 & 0 & $1(5)$ & 6 & $6(6)$ & - \\
\hline No. of fish examined & \multicolumn{4}{|c|}{10} & \multicolumn{4}{|c|}{20} \\
\hline No. of fish infected (\%) & 0.00 & 0.00 & 0.00 & 0.00 & $13(65)$ & 2 & 0.00 & 0.00 \\
\hline No. of Parasite species & 0.00 & 0.00 & 0.00 & 0.00 & 0.00 & 90 & $6.9(1-15)$ & $6.92 \pm 1.53$ \\
\hline No. of Parasites & 0.00 & 0.00 & 0.00 & 0.00 & 0.00 & 0.00 & 0.00 & 0.00 \\
\hline Total mean intensity & 0.00 & 0.00 & 0.00 & 0.00 & 0.00 & 0.00 & 0.00 & 0.00 \\
\hline
\end{tabular}


Table 3. comparison of prevalence (\%) and intensity ( $\mathrm{M} \pm$ S.E.) of different parasites infecting female and male examined Scarus fish in Red Sea of Rabigh.

\begin{tabular}{|c|c|c|c|c|c|c|c|c|}
\hline \multirow[b]{2}{*}{ Parasite sp. } & \multicolumn{4}{|c|}{ Female } & \multicolumn{4}{|c|}{ Male } \\
\hline & $\begin{array}{c}\text { No. of fish } \\
\text { Infected (\%) }\end{array}$ & $\begin{array}{l}\text { No. of } \\
\text { parasite }\end{array}$ & $\begin{array}{l}\text { Mean intensity } \\
\text { (range) }\end{array}$ & $\mathrm{M} \pm$ S.E & $\begin{array}{c}\text { No. of fish } \\
\text { infected (\%) }\end{array}$ & $\begin{array}{l}\text { No. of } \\
\text { parasite }\end{array}$ & $\begin{array}{l}\text { Mean intensity } \\
\text { (range) }\end{array}$ & $\mathrm{M} \pm \mathrm{S} . \mathrm{E}$ \\
\hline $\begin{array}{c}\text { Monogenea: } \\
\text { Diplectanum sp. }\end{array}$ & $13(68.4)$ & 118 & $9.08(2-30)$ & $9.08(2-30)$ & $3(27.3)$ & 57 & $19(7-25)$ & $19 \pm 6.0$ \\
\hline $\begin{array}{c}\text { Isopoda: } \\
\text { Praniza larva of Gnathia sp. }\end{array}$ & $4(21.05)$ & 7 & $1.75(1-3)$ & $1.75 \pm 0.48$ & - & - & - & - \\
\hline Digenea: Bucephalus sp. & $1(2.26)$ & 6 & $6(6)$ & - & - & - & - & - \\
\hline \multirow{2}{*}{ Lecithoclaster sp. } & $5(26.32)$ & 17 & $3.4(2-5)$ & $3.4 \pm 0.68$ & \multirow{2}{*}{-} & \multirow{2}{*}{-} & \multirow{2}{*}{ - } & \multirow{2}{*}{-} \\
\hline & $6(31.59)$ & 23 & $3.8(2-6)$ & $3.8 \pm 0.70$ & & & & \\
\hline Total Digenea & \multicolumn{4}{|c|}{19} & \multicolumn{4}{|c|}{11} \\
\hline No. of fish infected (\%) & - & 4 & - & - & - & 1 & - & - \\
\hline No. of Parasite species & - & 148 & - & - & - & 57 & - & - \\
\hline No. of Parasites & - & - & $6.43(1-30)$ & $6.43 \pm 0.85$ & - & - & $19(7-25)$ & $19 \pm 6.0$ \\
\hline Total mean intensity & - & - & - & - & - & - & - & $=$ \\
\hline
\end{tabular}

and was collected from the gills of Scarus sp. of fish from Rabigh only. This was lined up with Llewllyn [18], Rhode [4] and Whittington et al. [6]. They reported that most of the Monogenean gill parasite was found to be strictly specific to particular host. Llewllyn [18] proved that there was an exacting topographical relationship between a parasite and its host and this was probably an important factor in the mechanism of host specificity.

Praniza larva infested the two Scarus $s p$. with lower prevalence and intensity of parasites than Diplectanum sp. According to Sasal et al. [19] Diplectanum sp. could be classified as a specialist parasite of fish species (found only in one species) and Praniza larva as generalist (found in two or many host species).

In Rabigh, a statistically significant finding was observed where the female fish of Scarus $s p$. was infested with four parasite species while male fish had only one species (Diplectanum sp.). Prevalence of Monogenetic and overall parasite infestation was higher in female than male fishes, but the reverse was seen in the mean intensity. These findings may be due to mode of life, physiological and behavioral characters of each sex. Another interesting finding was found in Jeddah where no female fish showed any infestation as opposed to male that showed infestation with only parasitic crustacea (Isopoda and Copepoda). Our findings are different to Khalil [20], Barse [5], Adou et al. [21] and Aydogdu et al. [22] who found no definite difference in the prevalence and intensity of parasitic infestation according to fish sex.

In summary, this study identifies a variety of factors that might influence the parasitic fauna of Scarus fish species in the Red Sea coast of Saudi Arabia.

Further studies are warranted to identify additional factors in our region and 
explain the interesting finding of sex effect demonstrated in our work.

\section{References}

[1] Bush, A.O., Fernandez, J.C., Esch, G.W. and Seed, J.R. (2001) Parasitism: The Diversity and Ecology of Animal parasites. Cambridge University Press, Cambridge.

[2] Smith, J.I., Wotten, R. and Sommerville, C. (2007) The Pathology of the Early Stages of the Crustacean Parasite, Lernaeoera branchialis (L.), on Atlantic Cod, Gadus morhua L. Journal of Fish Diseases, 30, 1-11. https://doi.org/10.1111/j.1365-2761.2007.00787.x

[3] Morsy, K., El Fayoumi, H., Al Shahawy, G. and Fahmy, M. (2014) Diplectanum harid sp. nov. and Pseudohabdosynochus chlorostigma sp. nov. (Monogenea: Diplectanidae) from Scaridae and Serranidae Hosts of the Red Sea. World Journal of Fish and Marine Sciences, 6, 319-327.

[4] Rohde, K. (1977) Species Diversity of Monogenean Gill Parasites of Fish on the Great Barrier Reef. Proceedings of the Third International Coral Reef Symposium, Florida, May 1977, 585-591.

[5] Barse, A.M. (1998) Gill Parasites of Mummichogs, Fundulus heteroclitus (Teleostei: Cyprinodontidae): Effects of Season, Locality, and Host Sex and Size. Journal of Parasitology, 84, 236-244. https://doi.org/10.2307/3284476

[6] Whittington, I.D., Cribb, B.W., Hamwood, T.E. and Halliday, J.A. (2000) Host-Specificity of Monogenean (Platyhelminth) Parasites: A Role for Anterior Adhesive Areas? International Journal for Parasitology, 30, 305-320. https://doi.org/10.1016/S0020-7519(00)00006-0

[7] Khan, R.A. (2012) Host-Parasite Interaction in Some Fish Species. Journal of Parasitology Research, 2012, 7. https://doi.org/10.1155/2012/237280

[8] Jones, J.B. and Cabral, P. (1990) New Species of Hatschekia (Copepoda: Siphonostomatoida) from the Gills of South Pacific Fishes. Journal of the Royal Society New Zealand, 20, 221-232. https://doi.org/10.1080/03036758.1990.10426726

[9] Alexandra, S.G. (1994) Spatial and Temporal Variations of the Ectoparasites of Seven Reef Fish Species from Lizard Island and Heron Island, Australia. Marine Ecology Progress Series, 115, 21-30. https://doi.org/10.3354/meps115021

[10] Williams Jr., E.H. and Bunkley-Williams, L. (2003) New Records of Fish-Parasitic Isopods (Cymothoidae) in the Eastern Pacific (Galápagos and Costa Rica). Noticias de Galapagos, 62, 21-23.

[11] Toulah, F.H. (2006) Redescription of Praniza Larva (Crustacea: Isopoda: Gnathidae) a Temporary Ectoparasite of Certain Elasmobranch and Teleost Fishes from the Red Sea at Jeddah, Saudi Arabia. Alexandria Journal of Agricultural Research, 51, 69-74.

[12] Bakhrebah, A.O. (2006) A Brief Revision of the Genus Hatschekia leptoscari, Yamaguti, 1939 Parasitic on the Red Sea Fish "Scarus ferrugineus" in Saudi Arabia. Alexandria Journal of Agricultural Research, 51, 41-44.

[13] Kardousha, M.M. (2016) Parasites of Qatari Water of the Arabian Gulf: Current Status with an Annotated Checklist. International Journal of Recent Scientific Research, 7, 12388-12393.

[14] Bakhrebah, A.O. (1999) Identification and Comparative Study on the Different Parasites of Some Fishes, Family: Carangidae from the Red Sea Coast of Jaddah, (Saudi Arabia). M.Sc. Thesis, Girls' College of Education, Zoology Department, Jeddah.

[15] Bakhrebah, A.O. (2008) New Records for Hatshekia sargi (Copepoda: Hatscheki- 
dae) from Carcharhinid Fish in Red Sea of Saudi Arabia. Egyptian Journal of Aquatic Research, 34, 181-186.

[16] Bauer, O.N. (1957) Diseases of Carp in Fish Ponds in Leningrad, Velikie Luki and Novgorod Oblasts. Bull. of the All-Russian Scientific Research Institute, Freshwater Fisheries 13 Parasites and Diseases of Fish, Leningrad, 67-88.

[17] Ramamdan, H.H. and Shakweer, L.M. (1981) The Parasites of Some Fresh Water Egyptian Fishes, Their Seasonal Occurrence and Host Specificity. Bulletin of the Faculty of Science Assiut University, 21, 67-81.

[18] Llewllyn, J. (1956) The Host Specificity, Micro-Ecology, Adhesive Attitudes and Comparative Morphology of Some Trematode Gill Parasites. Journal of the Marine Biological Association of the United Kingdom, 35, 113-127. https://doi.org/10.1017/S0025315400009000

[19] Sasal, P., Trouve, S., Muller-Graf, C. and Morand, S. (1999) Specificity and Host Predictability: A Comparative Analysis among Monogenean Parasites of Fish. Journal of Animal Ecology, 68, 437-444. https://doi.org/10.1046/j.1365-2656.1999.00313.x

[20] Khalil, A.I. (1981) Studies on Some Parasitic Helminths in Some Marine Fish. M.Sc. Thesis, Alexandria University, Alexandria.

[21] Adou, Y.E., Blahoua, K.G., Kamelan, T.M. and N'douba, V. (2017) Prevalence and Intensity of Gill Monogenean Parasites of Tilapia guineensis (Bleeker, 1862) in Man-Made Lake Ayamé 2, Côte d'Ivoire According to Season, Host Size and Sex. International Journal of Biological and Chemical Sciences, 11, 1559-1576. https://doi.org/10.4314/ijbcs.v11i4.13

[22] Aydogdu, A., Pérez-Ponce de León, G., Emre, Y., Emre, N. and Yabac1, A. (2018) Prevalence and Intensity of Allocreadium isoporum (Digenea: Allocreadiidae) in Three Endemic Species of Cyprinids (Capoeta spp.) in Turkey, in Relation to Season, Host Size and Sex. Journal of Applied Ichthyology, 34, 129-135.

https://doi.org/10.1111/jai.13515 